\title{
Proliferating trichilemmal tumor of the nose *
}

\author{
Tumor triquilemal proliferante do nariz
}

\author{
Aristóteles Rosmaninho ${ }^{1}$ \\ Ana Oliveira ${ }^{1}$ \\ Manuela Selores ${ }^{3}$
}

\author{
Mónica Caetano ${ }^{2}$ \\ Teresa Pinto de Almeida ${ }^{1}$ \\ Rosário Alves ${ }^{2}$
}

\begin{abstract}
Proliferating trichilemmal tumor is a rare tumor originating in the external root sheath, that is usually found in the scalp of middle-aged or elderly females. Its histologic appearance may not correlate with its clinical behavior. In addition, there are no guidelines available for the treatment of these tumors, making its management a challenge for physicians. We report the case of a 53 year-old woman with a proliferating trichilemmal tumor on her nose, which is a very uncommon location for these lesions.

Keywords: Cysts; Nose neoplasms; Skin

Resumo: Tumor triquilemal proliferante é um tumor raro com origem na baínha radicular externa, que é encontrado geralmente no couro cabeludo de mulheres de meia idade ou idosas. A sua aparência histológica pode não se correlacionar com o seu comportamento clínico. Além disso, não há diretrizes disponíveis para o tratamento destes tumores, tornando a sua gestão um desafio para os médicos. Relatamos o caso de uma mulher de 53 anos com com um tumor triquilémico proliferante no nariz, que é uma localização muito incomum para essas lesões.

Palavras-chave: Cistos; Neoplasias nasais; Pele
\end{abstract}

\section{INTRODUCTION}

Proliferating trichilemmal tumor (PTT) is a rare, usually benign tumor of external root sheath derivation and have been reported with varying nomenclature, e.g., invasive pilomatrixioma, proliferating epidermoid cyst, trichoclamydocarcinoma, pilar tumor. ${ }^{1,2}$ They are slow growing lobular tumors, whose histologic hallmark is the presence of trichilemmal keratinization. ${ }^{3}$ Tumors with an invasive growth pattern or cytologic atypia have an unpredictable course and may be locally aggressive or metastasize. Thus, it has been suggested that even the classical PTT should be considered as carcinoma. ${ }^{4}$

\section{CASE REPORT}

A 53-year-old woman presented with a one-year history of a gradually enlarging lesion on the nose that was otherwise asymptomatic. The lesion had evidently been growing in the last 3 months. She denied trauma or insect bite at this location. Her medical history was unremarkable. On physical examination a localized, non-painful skin colored nodule with a smooth surface, soft consistency, measuring $0.5 \times 0.5 \mathrm{~cm}$ (Figure 1) was observed on the nose. There were no palpable adenomegalies. Total lesion surgical excision with a $0.5 \mathrm{~cm}$ margin of normal tissue was performed. Hematoxylin-eosin stain revealed a multilobular, noncapsulated tumor occupying all the dermis (Figure 2A). Lobules were formed by peripheral palisading of small basaloid cells, differentiating towards large keratinocytes with ample eosinophilic cytoplasm and abrupt keratinization without a granular layer (Figure 2B). Areas of calcification with cholesterol crystals were observed within the compact eosinophilic keratin (Figure 3A). The tumor cells showed moderate

Received on 07.09.2011.

Approved by the Advisory Board and accepted for publication on 08.11.2011.

* Study carried out at the Dermatovenereology Service of the Porto Hospital Center - Hospital Santo António (EPE-HSA) - Porto, Portugal.

Financial Support: None

Conflict of Interests: None

MD - Intern of Dermatovenereology - Dermatovenereology Service of the Porto Hospital Center - Hospital Santo António (EPE-HSA) - Porto, Portugal. MD - Hospital Assistant of Dermatovenereology - Dermatovenereology Service of the Porto Hospital Center - Hospital Santo António (EPE-HSA) - Porto, Portugal.

MD - Director of the Dermatovenereology Service of the Porto Hospital Center - Hospital Santo António (EPE-HSA) - Porto, Portugal. 


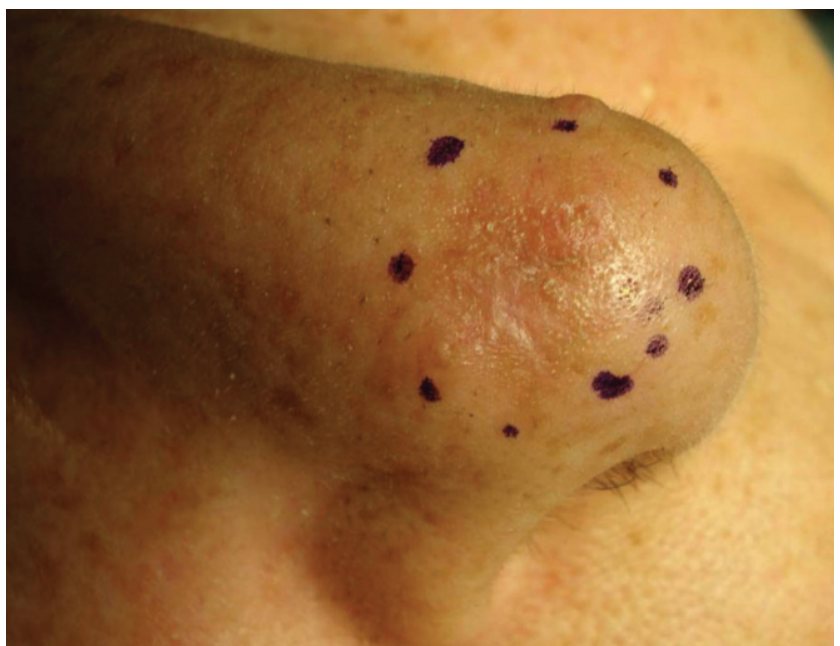

Figure 1: Asymptomatic nodule on the nose

nuclear atypia and scarce mitoses (Figure 3B). This was consistent with PTT. Wide surgical excision with a $1 \mathrm{~cm}$ margin of normal tissue was performed and no relapse was observed during the 8-month period of follow-up.

\section{DISCUSSION}

PTT is more frequent in middle-aged women and more than $90 \%$ of the lesions are localized on the scalp but the face, trunk, back, wrist and vulva can also be affected. ${ }^{1,2,5}$ Etiopathogenesis remains unknown but in most cases it appears to developed within the wall of a pre-existenting pilar cyst as complication of trauma and inflammation. ${ }^{6}$ It has also been reported to develop in nevus sebaceous and human papillomavirus has also been implicated. Nevertheless, PTT can occur de novo, as in our report. ${ }^{6}$ Histologically it occurs on a morphologic continuum, resembling the pilar cyst on one end of the spectrum and with features of malignant neoplasms on the other end. ${ }^{6}$ In addition to typical pilar cyst characteristics, extensive keratinocyte proliferation, variable cytologic atypia and mitotic activity are present. Brownstein et al concluded that the most characteristic feature of PTTs was trichilemmal keratinization. ${ }^{6} \mathrm{It}$ is accepted that cytologic atypia may be present in PTT that ultimately have a benign behaviour. However, the malignant variant also shows cytologic atypia and mitotic activity. This issue remains controversial since
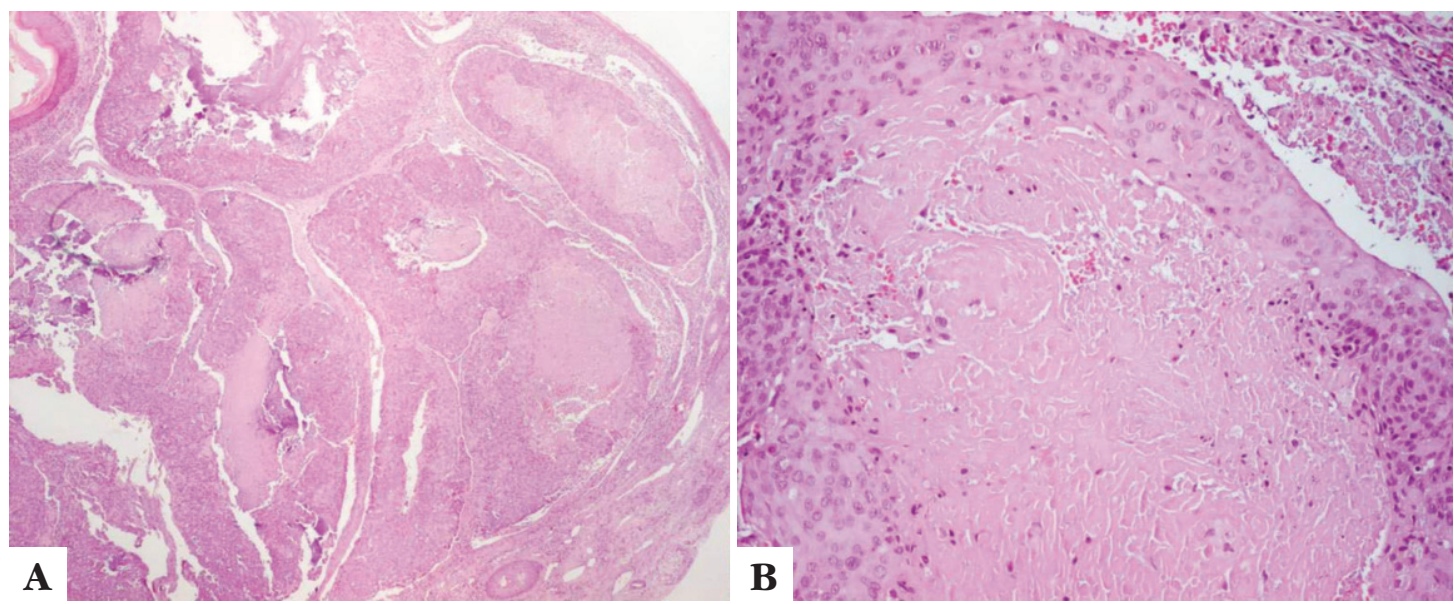

FIGURE 2: A.

Multilobular tumor (H\&E, x 4). B. Peripheral palisading of small basaloid cells, differentiating towards large keratinocytes and abrupt keratinization (H\&E, x 20)

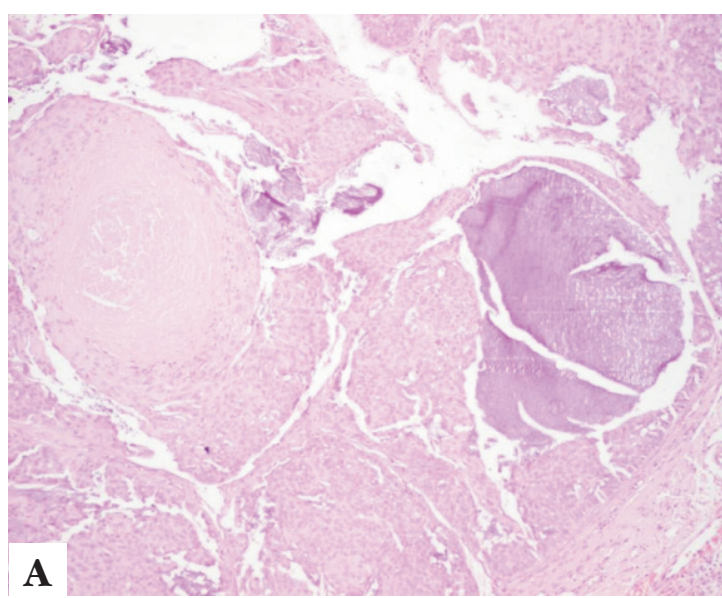

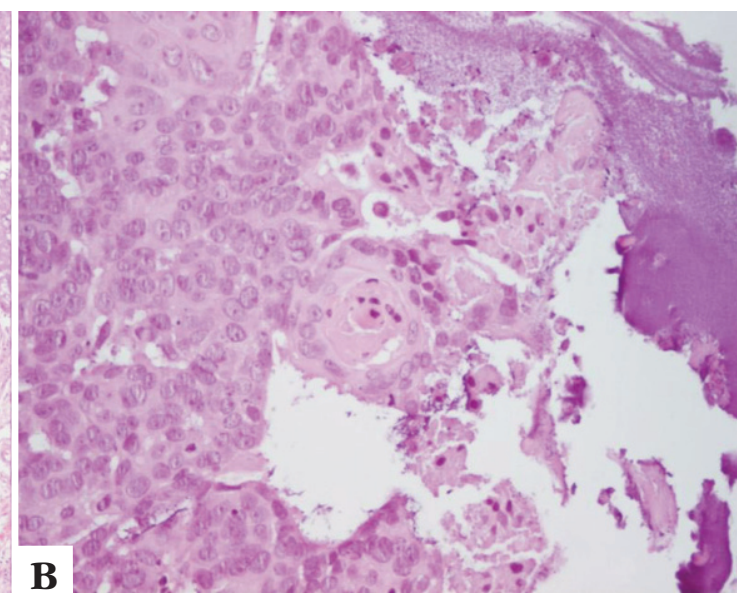

Figure 3: A. Areas of calcification with cholesterol crystals (H\&E, x 10). B. Moderate nuclear atypia (H\&E, x 20) 
tumors with little or no cytologic atypia may be aggressive, showing that their histologic appearance does not necessarily correlate with their biological behaviour. ${ }^{4}$ Therefore, as proposed by some authors, it is advisable to consider PTTs with those features as being at high risk of malignant transformation. ${ }^{2}$ It has been proposed that a nonscalp location, recent rapid growth, size larger than $5 \mathrm{~cm}$, infiltrative growth and important cytologic atypia with mitotic activity should be regarded as malignancy. ${ }^{2}$ Infiltrating tumors with marked atypia and pleomorphism may be histologically mistaken as squamous cell carcinoma (SCC) and trichilemmal carcinoma (TC). Trichilemmal-type keratinization, calcification, eosinophilic hyaline membrane surrounding the tumor, ordinary trichilemmal cyst, lack of a precursory epidermal lesion are all indicators of PTT rather than SCC. ${ }^{6}$ It is important to distinguish TC from the malignant variant of PTT, because the first does not have metastatic potential. TC is centered around a pilosebaceous unit and is composed of cytologically atypical, glycogen-containing or pale clear cell with basilar or full-thickness interfollicular epidermal spread; there is always a connection to the epidermis. ${ }^{8}$ Due to its rarity there are no guidelines available for the management of these tumors. However, complete local excision with long-term follow-up is still the standard treatment. ${ }^{9}$ A one-centimeter margin of normal tissue is recommended for the malignant variant. ${ }^{10}$ In summary, this is a case of a rare tumor on an uncommon location, with uncertain clinic behaviour and prognosis, which may represent a challenge when dealing with those lesions.

\section{REFERENCES}

1. Cavaleiro LHS, Viana FO, Carneiro CMM, Miranda MFR. Proliferating trichilemmal tumor - Case report. An Bras Dermatol. 2011;86(Supl1):S190-2.

2. Falpe AL, Reisenauer AK, Mentzel T, Rütten A, Solomon AR. Proliferating trichilemmal tumors: Clinicopathologic evaluation is a guide to biologic behavior. J Cutan Pathol. 2003;30:492-8.

3. Pinkus H. "Sebaceous cysts" are trichilemmal cysts. Arch Dermatol. 1969;99:544-55

4. Noto G, Pravata G, Arico M. Proliferating tricholemmal cyst should always be considered as a low grade carcinoma. Dermatology.1997;194:374-5.

5. Ye J, Nappi 0, Swanson PE, Patterson JW, Wick MR. Proliferating pilar tumors. A clinicopathologic study of 76 cases with a proposal for definition of benign and malignant variants. Am J Clin Pathol. 2004;122:566-74.

6. Brownstein MH, Arluk DJ. Proliferating trichilemmal cyst: a stimulant of squamous cell carcinoma. Cancer. 1981;48:1207-14.

7. Takeda H, Ikenaga S, Kaneko T, Nakajima K, Harada K, Hanada K, et al. Proliferating trichilemmal tumor developing in nevus sebaceous. Eur J Dermatol. 2010;20:664-5

8. Folpe AL, Reisenauer AK, Mentzel T, Rütten A, Solomon AR. Proliferating trichilemmal tumors: clinicopathologic evaluation is a guide to biologic behavior. J Cutan Pathol. 2003;30:492-8.
9. MacKie RM. Tumours of the skin. In: Rook A, Wilkinson DS, Ebling FJG, Champion $\mathrm{RH}$, Burton JL, editors. Textbook of dermatology. v. 3. 4th ed. St. Louis: Blackwell Mosby Book Distributors; 1986. p.2405-6.

10. Satyaprakash AK, Sheehan JS, Sanguez OP. Proliferating trichilemmal tumors: a review of the literature. Dermatol Surg. 2007;33:1102-8.

How to cite this article: Rosmaninho A, Caetano M, Oliveira A, Pinto-Almeida T, Selores M, Alves R. Proliferating trichilemmal tumor of the nose. An Bras Dermatol. 2012;87(6):914-6.

MAILING ADDRESS:

Aristóteles Rosmaninbo

Rua D. Manuel II, $s / n^{\circ}$

Edifício das Consultas Externas

4099-001 Porto, Portugal.

E-mail: arisrosmaninbo@gmail.com 